\title{
Cardiac Cavernous Hemangioma
}

National Cancer Institute

\section{Source}

National Cancer Institute. Cardiac Cavernous Hemangioma. NCI Thesaurus. Code C45750.

A hemangioma arising from the heart. It is characterized by the presence of cavernous vascular spaces. 